\title{
LITHOSPHERIC MAPPING BENEATH THE NORTH AMERICAN PLATE.
}

\author{
Griffin*WL ${ }^{1,2}$, O'Reilly SY ${ }^{1}$, Doyle BJ ${ }^{3}$, Kivi $K^{3}$, Coopersmith HG $^{4}$ \\ ${ }^{1}$ GEMOC ARC National Key Centre, Department of Earth and Planetary Sciences, Macquarie University, Australia; \\ ${ }^{2}$ Exploration and Mining, CSIRO, North Ryde, Australia; ${ }^{3}$ Kennecott Canada Exploration Ltd, Vancouver, B.C., Canada; \\ ${ }^{4}$ Great Western Diamond Co., Fort Collins, CO 80522, USA.
}

\section{INTRODUCTION}

The compositional structure of the subcontinental lithospheric mantle (SCLM) beneath the North American Plate (USA, Canada, W. Greenland) has been mapped in 3D using major- and trace-element data on Cr-pyrope garnets from ca 100 kimberlites, lamproites and lamprophyres in 26 areas (Fig. 1). A statistical classification scheme (Griffin et al., 2002) allows mapping of garnet compositional populations with depth to produce SCLM sections, which show the distribution of rock types and metasomatic processes. Inversion of a garnet-olivine thermometer (Gaul et al., 2000) has been used to map the variation in mean $\mathrm{X}_{\mathrm{Mg}}^{\text {olivine }}$ with depth.

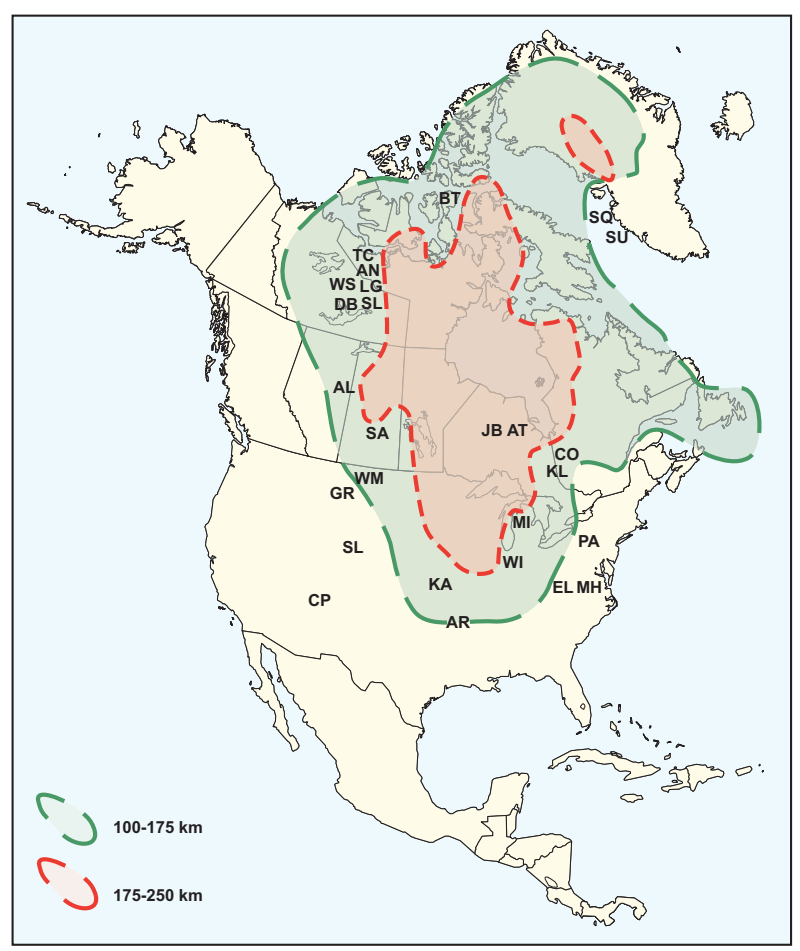

Figure 1: Map of N. America with contour outlines of the highvelocity lithospheric root at 100-175 km (red) and 175-250 km (green) after dataset of S. Grand.
Analysis of seismic tomography (Fig. 1) shows that known kimberlites do not sample the thickest and most depleted part of the North American SCLM; on a continental scale, as well as the regional scale, kimberlites and related rocks tend to be concentrated near major changes in lithospheric thickness. Available SCLM samples therefore represent the thinner and modified outer parts of the continental root.

\section{SCLM COMPOSITION}

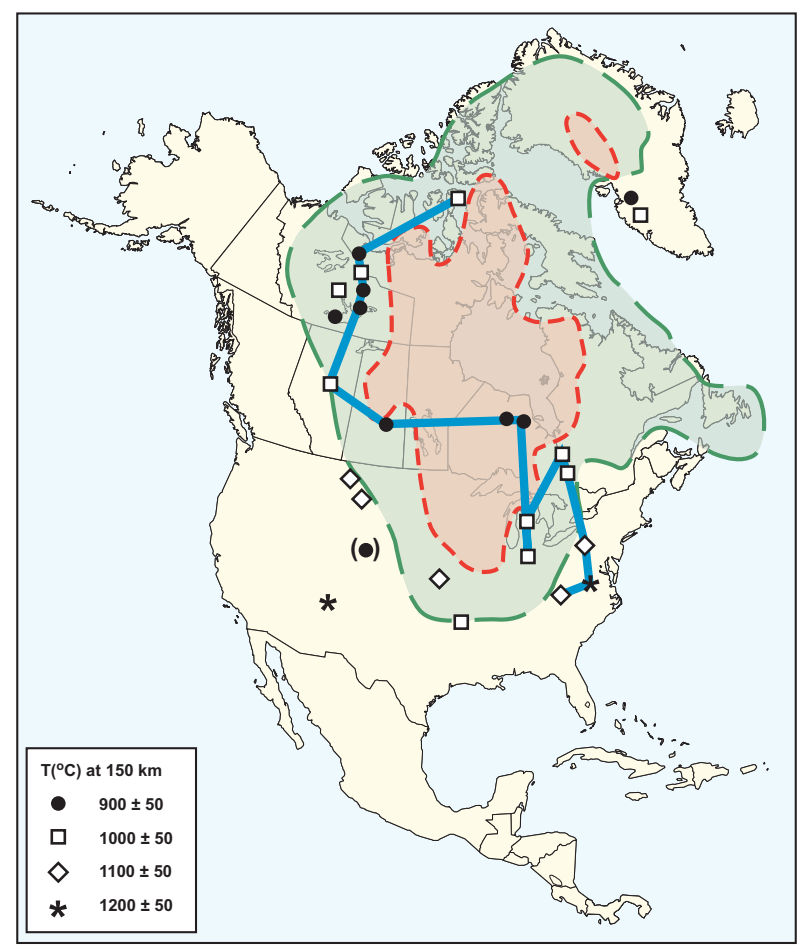

Figure 2: Contours as for figure 1 with temperature at $150 \mathrm{~km}$ (as derived from geotherms). The traverse line referred to in the text is also shown

SCLM composition shows broad correlations with the tectonothermal age of the crust at each locality, and strong correlations with seismic velocity at 100-175 km depths. The thickness of the depleted SCLM varies from $>200 \mathrm{~km}$ (Paleozoic in State Line District, Mesozoic in Saskatchewan), to $120-130 \mathrm{~km}$ in strongly modified 
younger areas (Colorado Plateau, N. Montana), and to ca $60 \mathrm{~km}$ beneath young orogens (Appalachians). The SCLM thickness is closely related to the geotherm, as reflected in the temperature at $150 \mathrm{~km}$ depth (Fig. 2)

Mean $\mathrm{X}_{\mathrm{Mg}}$ olivine is typically 92.6-93.2 in the upper parts of the SCLM beneath Archons, and beneath Protons with significant Archean prehistory (Figs. 1, 3); many Proton SCLM sections probably represent metasomatically modified Archean SCLM. Tectons and ossible "juvenile" Protons have less magnesian SCLM even at shallow depths (eg Colorado Plateau, 91.3; Kansas, 91.2; Virginia 90.2). The highest mean $\mathrm{X}_{\mathrm{Mg}}$ olivine is found in localities (Michigan, Hudson Bay) on the edge of the highest-velocity part of the root, where magnesian compositions also extend to greatest depth (Fig. 3); this suggests that the central cratonic "root" represents the extension of this highly depleted material to depths $>175 \mathrm{~km}$.

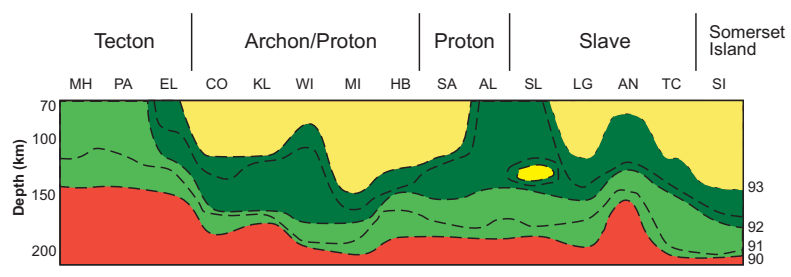

Figure 3: Distribution of $\mathrm{X}_{\mathrm{mg}}$ of olivine with depth along the traverse shown in figure 2 .

\section{SCLM STRUCTURE}

Many SCLM sections are relatively homogeneous in terms of rock type distribution and $\mathrm{X}_{\mathrm{Mg}}$ olivine, except for a rise in fertility and a drop in $\mathrm{X}_{\mathrm{Mg}}$ olivine to asthenospheric values $(\leq 90.5)$ over distances of $10-50 \mathrm{~km}$ toward the lithosphereasthenosphere boundary. The transition from depleted lithosphere to asthenosphere is relatively sharp under the eastern part of the craton, and broader beneath Protons (Figure 3); this may reflect more extensive metasomatism beneath the Protons.

Several sections show marked stratification, typically with the upper layer being more depleted, and one or more sharply defined discontinuities at $120-160 \mathrm{~km}$ depth. In terms of trace-element depletion,the upper part of the central Slave Craton stands out dramatically from other parts of the craton (Fig. 4); this appears to reflect greater degrees of later metasomatic re-enrichment outside the Slave Province. In West Greenland, interleaving of depleted and fertile SCLM may reflect tectonic stacking, related to the development of the nearby major Proterozoic suture zone. Other cases (Lac de Gras, N. Michigan, Saskatchewan; Fig. 4) are interpreted as the result of plume subcretion beneath a depleted SCLM of moderate thickness. Synchroneity between kimberlite intrusion and basin subsidence in the latter two cases is consistent with suggestions (Kaminski and Jaupart 2000) that plume modification of the SCLM caused the development of these major intracratonic basins.

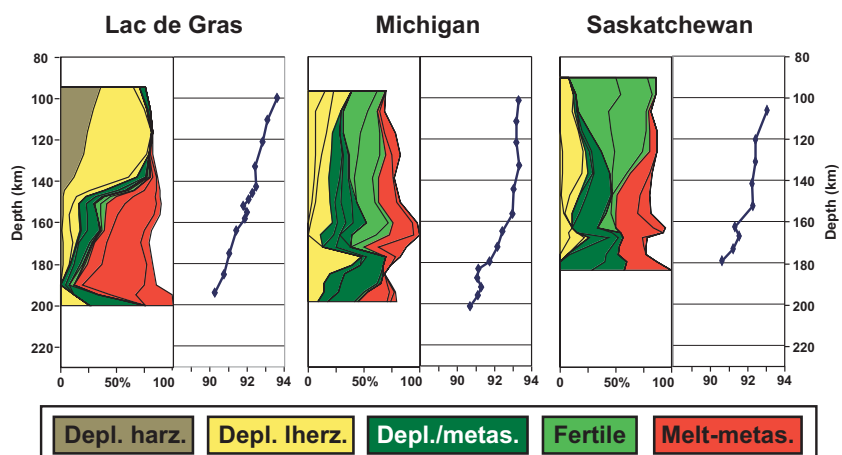

Figure 4: Rock-type sections for the Slave (Lac de Gras), Michigan and Saskatchewan regions.

\section{DISCUSSION}

This analysis reveals strong correlations between the degree of depletion $\left(\mathrm{X}_{\mathrm{Mg}}{ }^{\text {olivine }}\right.$ ), the geotherm and tectonothermal age. Depletion and lithospheric temperature are negatively correlated, and thus have mutually reinforcing effects on seismic velocity (Fig. 3). These correlations simplify the interpretation of seismic tomography in terms of lithosphere composition and history. The central core of the North American continent has an extensive, highly depleted root that extends well below $175 \mathrm{~km}$, but is poorly sampled by known kimberlites. This root is essentially continuous beneath the Early-Mid Proterozoic mobile belts of the Canadian Shield. The outer parts of the root have been modified by introduction of material from the asthenosphere in both Archean and later time, producing a belt of varying thickness in which the SCLM has a less magnesian mean composition, and tends to be thinner. The intermediate seismic velocity of Tecton areas such as the Appalachians reflects both the fertile nature of the SCLM, and moderately elevated geotherms. Areas such as the Colorado Plateau, which has a moderately fertile mantle and is currently experiencing thermally driven uplift, show anomalously low seismic velocity in the $100-175 \mathrm{~km}$ depth range.

The present lithospheric architecture reflects an interplay between the buoyancy of Archean SCLM, its modification along rifts and mobile belts, the generation of juvenile Proterozoic and Phanerozoic SCLM, and the subcretion of plume head material. Lithospheric mapping, combined with 
interpretation of seismic tomography, indicates that relict Archean SCLM probably is present, at least at shallow levels, beneath much of the Proterozoic part of the N. American plate. This conclusion has important tectonic implications and is being tested by in-situ Re-Os analysis of sulfides in mantle-derived xenoliths.

\section{REFERENCES}

Gaul, O.F., Griffin, W.L., O’Reilly, S.Y. and Pearson, N.J. 2000. Mapping olivine composition in the lithospheric mantle. Earth Planet. Sci. Lett. 182, 223-235.

Griffin, W.L., Fisher, N.I., Friedman, J.H., O'Reilly, S.Y. and Ryan, C.G., 2002. Cr-pyrope garnets in the lithospheric mantle. II. Compositional populations and their distribution in time and space. Geochemistry, Geophysics and Geosystems

Kaminski, E. and Jaupart, C. 2000. Lithosphere structure beneath the Phanerozoic basins of North America. Earth Planet. Sci. Lett. 178, 139-149.

Contact: Bill Griffin, GEMOC ARC National Key Centre, Department of Earth and Planetary Sciences, Macquarie University, NSW, 2109, Australia: bill.griffin@mq.edu.au; www.es.mq.edu.au/GEMOC/ 